\title{
The response of soybean plants grown in newly reclaimed soil to different fungal species of arbuscular mycorrhizal and phosphorus fertilization
}

\author{
Salem Al-Amri \\ Department of biology, College of Science and ART, Shaqra University, Saudi Arabia
}

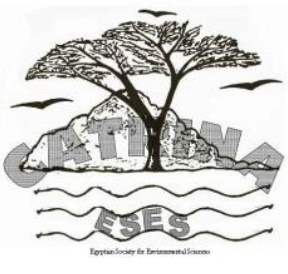

A pot experiment was conducted to study the response of soybean plants (Glycine max), grown in soil collected from the newly reclaimed area, to root colonization with the different species of arbuscular mycorrhizal (Glomus moseae, Glomus monosporum, and Gigaspora margarita) and soil phosphorus fertilization. Fungal phosphatases and succinate dehydrogenase (vital stain) activities as enzyme markers were also investigated to detect the physiological activity of the mycorrhizal fungi. Two concentrations of $\mathrm{KH}_{2} \mathrm{PO}_{4}\left(0\right.$ and $0.5 \mathrm{~g} \mathrm{~kg}^{-1}$ soil $)$ were used. External addition of soluble phosphorus increased all growth parameters, nutrient contents and biochemical parameters of both the mycorrhizal and nonmycorrhizal plants. The mycorrhizal colonization significantly increased some of the growth parameters, $\mathrm{P}$ and $\mathrm{N}$ concentrations in root and shoot tissues, root nodulation, acid and alkaline phosphatase activities and total soluble proteins in root extracts when compared to nonmycorrhizal plants. Such stimulations in these parameters were highly related to the level of each species of mycorrhizal colonization in the root tissues of soybean plants, particularly in soil without phosphorus. The addition of phosphorus to soil reduced the level of mycorrhizal colonization in the soybean root tissues, and consequently the mycorrhizal benefits. The efficiency of mycorrhizal fungi in this study for stimulating plant growth and nutrient contents was positively related to the activity of fungal succinate dehydrogenase stained in the root tissues.

Keywords: mycorrhizal fungi; growth and nutrition; soybean; P fertilization, vital stain.

\section{INTRODUCTION}

Soybean (Glycine $\max L$.) is still one of the most important oil seed crops in the world (Al-Kahtani, 1989; Sarabia et al., 2017) and like other oil crops requires application of phosphorus fertilization when grown in poor soil, like those of sandy loamy soil, which considered below the critical phosphorus value for the optimal plant growth (Abdel-Fattah, 1997; Tang et al., 2009). Enhancing growth and yield of soybean through increasing the productivity per unit of area, as well as expanding the cultivated area in newly reclaimed lands, is one of the major important goals. However, excessive application of phosphorus fertilizers causes environmental problems (Gosling et al., 2016; Lehman \& Taheri, 2017).

Phosphorus is a highly important mineral for plant growth and its deficiency can greatly decrease the development of plant growth (Ibrahim et al., 2011; Karasawa and Takahasi, 2015). Arbuscular mycorrhizal associations are one target of acquiring adequate supplies of phosphorus for soils with low available phosphorus (Al-Amri et al., 2013; Sheng et al., 2013; Higo et al., 2018). Increased growth, nodulation and some of physiological and biochemical aspects of soybean plants in the presence of arbuscular mycorrhizal fungi (AMF) has been attributed mainly to the enhanced uptake of phosphorus (Smith et al., 2011; Abdel-Fattah and Asrar, 2012; Karasawa and Takahasi, 2015; Vitorazi et al., 2017). This is extremely supportive since external hyphae of AMF can absorb phosphorus beyond the depletion zones around roots and root hairs and transport it to root tissues (Smith and Gianinazzi-Pearson, 1988; Beauregard et al., 2013; Wang et al., 2017). Arbusclar mycorrhizal fungiare also highly concerned in transferring nitrogen from one plant to another (He et al., 2003; Abdel-Fattah et al.,
2014) or taking up $\mathrm{N}$ indirectly and transferring it to the host roots (Ames et al., 1983), stimulating also the utilization of different nitrogen forms (Hodge et al., 2001; Liu et al., 2015; Sawers et al., 2017).

Alkaline and acid phosphatase activities can be increased by AMF colonization (Gianinazzi-Pearson and Gianinazzi, 1987; Filho et al., 2017). In addition, alkaline phosphatase has been identified, as an active enzyme in arbuscular mycorrhizae, using gel electrophoresis (Abdel-Fattah, 1997). Moreover, Ezawa and Yoshida (1994) reported that mycorrhiza-specific phosphatase was detected only in the mycorrhizal root extract, and it was the fungal origin (Daei et al., 2009). Furthermore, Tisserant et al., (1993) stated that this enzyme may somehow be involved in the processes of phosphorus acquisition in mycorrhizal plants. In meantime, the residual phosphorus from continuous applications of high rates of mineral phos-phorus, to soil, led to increasing soil phosphorus satur-ation concentration and general soil fertility, which in turn inhibits AMF development in the asso-ciated root tissues (Smith et al., 2011; Higo et al., 2018). Therefore, the aim of this study was to examine the effects of different species of arbuscular mycorrhizal fungi on plant growth, phosphorus and nitrogen content, activities of acid and alkaline phosphatases, nodulation and photosynthetic pigments of soybean plants grown under two levels of soil P. The changes in succinate dehydrogenase activity in ti- ssue of soy-bean roots in correlation to the efficiency of AMF and their stimulation of plant growth and nutrition were also investigated.

\section{Soil used \\ MATERIALS AND METHODS}

The soil used was obtained from the new reclaimed

\footnotetext{
*Corresponding author, E-mail:phd1618@hotmail.com
} 
agricultural site of Abba, Saudi Arabia. Mechanical and chemical soil analyses were carried out which revealed that the soil texture was sandy loam soil consisting of $43.2 \%$ clay, 28.1 silt, and 28.7 sand and with the following physical and chemical characteristics: $\mathrm{pH}$ (water) 7.6; organic matter, 13.9; available $\mathrm{P}$ (Olsen), $15 \mathrm{mg} / \mathrm{kg}$; available $\mathrm{N}, 18 \mathrm{mg} / \mathrm{kg} ; \mathrm{K}, 23$ $\mathrm{mg} / \mathrm{kg} ; \mathrm{Mg}, 31 \mathrm{mg} / \mathrm{kg}$. Electrical conductivity was 21 $\mathrm{dS} \mathrm{m}-1$. The soil was sterilized before using in the autoclave at $121^{\circ} \mathrm{C}$ for three successive times. Phosphorus was added to the soil as $\mathrm{KH}_{2} \mathrm{PO}_{4}$ at planting into two levels ( 0 and $0.5 \mathrm{~g} / \mathrm{Kg}$ soil).

\section{Arbuscular mycorrhizal (AM) inoculum prepa- ration}

Three species of mycorrhizal fungi, Glomus mosseae, (Nicol. \& Gerd.); Glomus monosporum (Gerd. \& Trappe) and Gigaspora margarita (Becker \& Hall); inocula, consisting of hyphae, soil, spores and infected roots fragments of onion plants (Allium cepa $L$ ), were sed. The stock culture of mycorrhizal fungi was collected from the Experimental Station of Plant Production, College of Food and Agricultural Science, King Saud University. The selected native arbuscular mycorrhizal fungi were mixed with soil before planting. The inoculum, consisting of $15 \mathrm{~g}$ of rhizo-sphere trap soil and $0.5 \mathrm{~g}$ of infected segments of onion root segments of the respective mycorrhizal species, was mixed with soil per each pot. Non-mycorrhizal treatments received a water filtrate $(5 \mathrm{ml} /$ plant $)$ of the inocula of the respective AMF to include other microorganisms associated with the mycorrhizal inoculums. The filtrate was passed through a $30-\mu \mathrm{m}$ nylon sieve to remove any spores of my-corrhizal fungi.

\section{Experimental design}

A glasshouse pot experiment with the soybean plant hybrid 20 was carried out with two factors in a fully factorial randomized design. The treatments consisted of four arbuscular mycorrhizal fungi [Glomus mosseae, Glomus monosporum, Gigaspora margarita (AMF) and non-inoculated (AMF)] and two levels of phosphorus fertilization (0.0, control), and $0.5 \mathrm{~g} \mathrm{Kg}$-soil of $\mathrm{KH}_{2} \mathrm{PO}_{4}$ ). Ten time replica were used for each of the eight treatments (one plant / each pot) to provide 90 pots as total.

\section{Plant and growth conditions}

Seeds of soybean (Glycine max hybrid 20) were surface disinfected by soaking in $8 \%$ sodium hypochlorite for $10 \mathrm{~min}$, consequently rinsed with sterile de-ionized water (three times) and left to germinate for $72 \mathrm{~h}$ at room temperature in moist autoclaved vermiculate. Germinated seedlings were planted (one plant/pot) into plastic pots $(40 \mathrm{~cm}$ in diameter) containing $4 \mathrm{~kg}$ of disinfected sandy loam soil. Pots were divided into two groups according to the $\mathrm{P}$ concentration. $\mathrm{KH}_{2} \mathrm{PO}_{4}$ was added and mixed with the soil during planting. Each group of pots was divided into 4 sets according to the mycorrhizal treatments as described before. The mycorrhizal inocula, for each respective species, were placed $4 \mathrm{~cm}$ depth in the soybean seedling medium at planting time.
The non-mycorrhizal treatments, for each species, were provided with filtrated washings of an equal amount of the mycorrhizal inocula to provide the same associated microorganisms other than mycorrhizal propagules. All plants were inoculated with Rhizobium japonicum strain G5 after 2 weeks of planting. All pots were completely randomized in the glasshouse under natural day length and light intensity (spring-summer) and watered regularly to near field capacity with tap water. After 5 weeks, all plants received $32 \mathrm{mg} \mathrm{S}$ (as $\mathrm{K}_{2} \mathrm{SO}_{4}$ ) per plant. Ten plants from each treatment were harvested 9 weeks after planting.

\section{Growth Measurements}

At harvest, fresh and dry weight of roots and shoots were recorded. Shoot height per plant was also determined. Four plants for each treatment were randomly chosen for the determination of nodule dry weight and number. Shoots and roots were dried at 80 ${ }^{\circ} \mathrm{C}$ for $48 \mathrm{~h}$ and then ground separately for $\mathrm{P}$ and $\mathrm{N}$ content estimation. Total phosphorus was determined by the Vando-molybdate colorimetric method (Jackson, 1973). Total nitrogen was determined by the Kjeldahl method (Nelson and Sommers, 1973). Photosynthetic pigments (chlorophyll a, chlorophyll b and carotenoids) in soybean leaves were estimated according to Hiscox \& Israelstam (1979). The extraction was made from $150 \mathrm{mg}$ of fresh sample in acetone $(85 \%)$ in the dark at room temperature and was measured with a UV/VIS spectrophotometer (Shimadzu UV-160, Kyoto, Japan).

Immediately after harvesting, a part of the root system was taken carefully and washed in ice-cold distilled water to remove all soil particles and then extracted by macerating the detached roots in the cooled mortar at $4{ }^{\circ} \mathrm{C}$ using $0.1 \mathrm{M}$ borate buffer $(\mathrm{pH}$ 8.8). The macerated extract was centrifuged at 15000 rpm for $30 \mathrm{~min}$ using a cooling centrifuge. Total soluble and alkaline and acid phosphatases were determined according to the method of GianinazziPearson and Gianinazzi, (1976). Phosphatase activates were expressed as the unit of enzyme activity which transforms $1 \mu \mathrm{mol}$ of the substrate (P-nitrophenol phosphate) under specific experimental conditions. Total soluble protein in root extract was determined by the method of Bradford (1976). Protein concentration was estimated against a standard curve of bovine serum albumin.

For total mycorrhizal colonization (TB), one gram of the root system for each treatment was cut immediately after harvest into 3-5 $\mathrm{mm}$ pieces in ice box after clearing and staining with trypan blue method (Phillips \& Hayman, 1970) or by staining for succinate dehydrogenase (SDH) following the method of Smith and Gianinazzi-Pearson, (1990) activity. Mycorrhizal colonization levels (F, frequency of mycorrhizal colonization; $\mathrm{M}$, the intensity of mycorrhizal colonization and $\mathrm{A}$, arbuscular frequency) in the root segments stained to estimate total (TB) or living (SDH) were investigated according to the method of Trouvelot et al., (1986). Mycorrhizal dependency (MD) was defined as a percentage of a plant growth subjected to 
AMF application (Menge et al., 1978), and calculated from the following formula as:

\section{$[(\mathrm{M}-\mathrm{NM}) / \mathrm{NM}] \times 100$}

Where, $\mathrm{M}$ is parameter value of mycorrhizal plants and $\mathrm{NM}$ is parameter value of non-mycorrhizal plants.

\section{Statistical analysis}

All data were statistically analyzed, to compare the differences among different treatments, using two-way factorial analysis of variance (ANOVA) followed by Duncan's multiple range test. Each comparison is performed at a significance level $(p \leq 0.5)$.

\section{RESULTS}

\section{Growth response}

Addition of soluble phosphorus to the soil improved plant growth of both mycorrhizal and non-mycorrhizal plants (Table 1). In non-fertilized soil, shoot height, fresh and dry matter of shoots and roots of mycorrhizal soybean plants were significantly higher when compared to the non-mycorrhizal plants. Such increases in these responses were linked to the degree of mycorrhizal colonization. The magnitude of the mycorrhizal response varied between the three mycorrhizal fungi. In this connection, Glomus mosseae gave the highest growth response followed by Glomus monosporum. On the other hand, no significant differences were observed in growth response between mycorrhizal (except $G$. mosseae treatment) and nonmycorrhizal plants grown in soil amended with phosphorus fertilization.

\section{Photosynthetic pigments}

The photosynthetic pigments content (chlorophyll a, chlorophyll $b$ and carotenoids) in mycorrhizal leaves of soybean plants were significantly greater than those of non-mycorrhizal plants grown in soil un-amended with phosphorus (Table 2). Such increases in these contents were varied between the mycorrhizal fungi used in this study. Generally, the addition of soluble phosphorus to the soil significantly enhanced the photosynthetic pigment contents in mycorrhizal and non-mycorrhizal soybean plants. On the other hand, no significant differences in carotenoids content were observed between mycorrhizal and nonmycorhizal plants grown in soil amended with phosphorus.

\section{Acid and alkaline phosphatase enzymes and soluble protein}

Phosphorus addition to the soil significantly decreased the activities of acid and alkaline phosphatases and total soluble protein in roots of mycorrhizal and non-mycorrhizal plants as compared to the non-amended $\mathrm{P}$ treatments table 3. However, mycorrhizal colonization significantly improved the contents of acid and alkaline phosphatase activities than those in roots of non-mycorrhizal plants, particularly in P deficient soil. Such increases in these activities in roots of soybean plants in response to mycorrhizal effects were related to each respective mycorrhizal colonization. On the other hand, no significant difference in acid phosphatase activity was observed between mycorr-hizal and non-mycorrhizal plants grown in soil amended with soil phosphorus.

Table (1): Effect of phosphate fertilization and different species of mycorrhizal inocula on the growth parameters of soybean plants grown under experimental condition.

\begin{tabular}{|c|c|c|c|c|c|c|}
\hline \multirow{2}{*}{\multicolumn{2}{|c|}{ Treatments }} & \multicolumn{5}{|c|}{ Growth Parameters (g plant $^{-1}$ ) } \\
\hline & & \multicolumn{2}{|c|}{ Fresh weight } & \multicolumn{2}{|c|}{ Dry weight } & \multirow[b]{2}{*}{$\begin{array}{l}\text { Shoot height } \\
\left(\mathrm{cm}^{-1}\right)\end{array}$} \\
\hline $\begin{array}{l}\mathrm{KH}_{2} \mathrm{PO}_{4} \text { dose } \\
\left(\text { g.kg- }^{-1} \text { soil }\right)\end{array}$ & AMF status & Shoot & Root & Shoot & Root & \\
\hline \multirow{4}{*}{$\mathbf{0}$} & Non-AMF & $09.05^{\mathrm{cd}}$ & $5.46^{\mathrm{d}}$ & $1.90^{\mathrm{c}}$ & $0.82^{\mathrm{d}}$ & $48.1^{\mathrm{c}}$ \\
\hline & Glomus mosseae & $15.01^{\mathrm{ab}}$ & $8.11^{\mathrm{ab}}$ & $3.56^{\mathrm{a}}$ & $1.23^{\mathrm{b}}$ & $55.8^{\mathrm{b}}$ \\
\hline & Glomus monosporum & $13.08^{\mathrm{b}}$ & $7.28^{\mathrm{b}}$ & $3.11^{\mathrm{b}}$ & $1.02^{\mathrm{c}}$ & $52.7^{\mathrm{ab}}$ \\
\hline & Gigaspora margarita & $10.28^{\mathrm{c}}$ & $6.23^{\mathrm{c}}$ & $2.29^{\mathrm{b}}$ & $0.95^{\mathrm{c}}$ & $50.8^{\mathrm{c}}$ \\
\hline Mean $\left(\mathrm{MD}^{*} \%\right)$ & & $41.3^{\mathrm{a}}$ & $32.0^{\mathrm{a}}$ & $57.2^{\mathrm{a}}$ & $24.7^{\mathrm{a}}$ & $10.4^{\mathrm{a}}$ \\
\hline \multirow{4}{*}{0.5} & Non-AMF & $15.77^{\mathrm{b}}$ & $7.50^{\mathrm{ab}}$ & $3.24^{\mathrm{b}}$ & $1.11^{\mathrm{c}}$ & $60.3^{\mathrm{a}}$ \\
\hline & Glomus mosseae & $16.44^{\mathrm{a}}$ & $8.80^{\mathrm{a}}$ & $3.84^{\mathrm{a}}$ & $1.40^{\mathrm{a}}$ & $62.1^{\mathrm{a}}$ \\
\hline & Glomus monosporum & $15.99^{\mathrm{b}}$ & $7.30^{\mathrm{ab}}$ & $3.61^{\mathrm{ab}}$ & $1.22^{\mathrm{b}}$ & $61.2^{\mathrm{a}}$ \\
\hline & Gigaspora margarita & $15.88^{\mathrm{b}}$ & $7.10^{\mathrm{ab}}$ & $3.30^{\mathrm{b}}$ & $1.15^{\mathrm{c}}$ & $60.2^{\mathrm{a}}$ \\
\hline Mean (MD\%) & & $2.11^{\mathrm{b}}$ & $3.11^{\mathrm{b}}$ & $10.6^{b}$ & $13.2^{b}$ & $1.43^{b}$ \\
\hline LSD (0.05) & & 0.655 & 0.388 & 0.201 & 0.155 & 3.042 \\
\hline
\end{tabular}

Mycorrhizal dependency $\left(\mathrm{MD}^{*}\right)=[(\mathrm{M}-\mathrm{NM}) / \mathrm{NM}] \times 100$, Values of mycorrhizal treatments or MD separately in each column either followed by the same letter(s) are not significantly different at $p \leq 0.05$ (Duncan's Multiple Range test). Each value represents the mean of 5 replicates and LSD represents the values between treatments. 
Table (2): Effect of phosphate fertilization and different species of mycorrhizal colonization on the photosynthetic pigments measurement, chlorophyll a; chlorophyll $\mathrm{b}$ and carotenoids of soybean leaves grown in a sterilized soil.

\begin{tabular}{|c|c|c|c|c|}
\hline \multirow{2}{*}{\multicolumn{2}{|c|}{$\begin{array}{l}\text { Treatments } \\
\text { AMF status }\end{array}$}} & \multicolumn{3}{|c|}{ Photosynthetic pigments $\left(\mu \mathrm{g} \mathrm{g}^{-1}\right.$ ) } \\
\hline & & $\begin{array}{l}\text { Chlorophyll } \\
\text { "a" }\end{array}$ & $\begin{array}{c}\text { Chlorophyll } \\
\text { "b" }\end{array}$ & Carotenoids \\
\hline \multirow{3}{*}{$\mathbf{0}$} & Non-AMF & $1291^{\mathrm{c}}$ & $765^{d}$ & $275^{\mathrm{d}}$ \\
\hline & Glomus mosseae & $1566^{\mathrm{d}}$ & $925^{\mathrm{b}}$ & $304^{\mathrm{c}}$ \\
\hline & Glomus monosporum & $1432^{\mathrm{d}}$ & $880^{\mathrm{c}}$ & $299^{c}$ \\
\hline \multirow[b]{2}{*}{ Mean (MD* \%) } & Gigaspora margarita & $1315^{\mathrm{c}}$ & $805^{\mathrm{b}}$ & $280^{\mathrm{d}}$ \\
\hline & & $11.4^{\mathrm{a}}$ & $13.6^{\mathrm{a}}$ & $7.03^{\mathrm{a}}$ \\
\hline \multirow{4}{*}{0.5} & Non-AMF & $1688^{\mathrm{b}}$ & $830^{\mathrm{b}}$ & $337^{\mathrm{b}}$ \\
\hline & Glomus mosseae & $2013^{a}$ & $995^{\mathrm{a}}$ & $367^{\mathrm{a}}$ \\
\hline & Glomus monosporum & $1740^{\mathrm{b}}$ & $928^{\mathrm{b}}$ & $349^{\mathrm{b}}$ \\
\hline & Gigaspora margarita & $1710^{\mathrm{b}}$ & $866^{\mathrm{b}}$ & $348^{\mathrm{b}}$ \\
\hline Mean (MD* \%) & & $7.88^{b}$ & $12.0^{\mathrm{a}}$ & $5.24^{\mathrm{ab}}$ \\
\hline LSD (0.05) & & 88.4 & 33.5 & 20.11 \\
\hline
\end{tabular}

Table (3): Quantitative changes in protein, soluble acid and alkaline phosphatase activities of mycorrhizal and non-mycorrhizal soybean roots grown in a sterilized soil with or without phosphorus fertilizer.

\begin{tabular}{|c|c|c|c|c|}
\hline \multicolumn{2}{|c|}{ Treatments } & \multicolumn{2}{|c|}{$\begin{array}{c}\text { Phosphatase activities } \\
(\mathrm{mU} / \mathrm{ml})\end{array}$} & \multirow{2}{*}{$\underset{(\mu \text { grogfwt }}{\text { Protein }}$} \\
\hline $\begin{array}{l}\mathrm{KH}_{2} \mathrm{PO}_{4} \text { dose } \\
\text { (g.kg-1 }{ }^{-1} \text { soil) }\end{array}$ & AMF Inoculum & Acid & Alkaline & \\
\hline \multirow{4}{*}{0.0} & Non-AMF & $679^{\mathrm{ab}}$ & $210^{\mathrm{c}}$ & $439^{c}$ \\
\hline & Glomus mosseae & $720^{\mathrm{a}}$ & $298^{\mathrm{a}}$ & $642^{\mathrm{a}}$ \\
\hline & Glomus monosporum & $699^{\mathrm{b}}$ & $240^{\mathrm{b}}$ & $530^{\mathrm{b}}$ \\
\hline & Gigaspora margarita & $680^{\mathrm{ab}}$ & $222^{\mathrm{c}}$ & $490^{\mathrm{bc}}$ \\
\hline Mean (MD* \%) & & $3.04^{\mathrm{a}}$ & $20.6^{\mathrm{a}}$ & $26.2^{\mathrm{a}}$ \\
\hline \multirow{4}{*}{0.5} & Non-AMF & $660^{\mathrm{ab}}$ & $135^{\mathrm{e}}$ & $410^{\mathrm{c}}$ \\
\hline & Glomus mosseae & $688^{\mathrm{ab}}$ & $165^{\mathrm{d}}$ & $512^{\mathrm{b}}$ \\
\hline & Glomus monosporum & $670^{\mathrm{ab}}$ & $148^{\mathrm{e}}$ & $488^{\mathrm{bc}}$ \\
\hline & Gigaspora margarita & $665^{\mathrm{ab}}$ & $138^{\mathrm{e}}$ & $423^{\mathrm{c}}$ \\
\hline Mean (MD* \%) & & $2.17^{\mathrm{a}}$ & $11.4^{\mathrm{b}}$ & $15.7^{\mathrm{b}}$ \\
\hline LSD (0.05) & & 15.3 & 11.7 & 1.359 \\
\hline
\end{tabular}

MD* = Mycorrhizal dependency. Values of mycorrhizal treatments or MD separately in each column either followed by the same letter(s) are not significantly different at $p \leq 0.05$ (Duncan's multiple range test). Each value represents the mean of 5 replicates and LSD represents the values between mycorrhizal treatments. Enzyme activity expressed as $\mathrm{mU} / \mathrm{ml}$ of root extract, where $\mathrm{U}$, one enzyme activity which transforms $1 \mu \mathrm{mol}$ of substrate (PNNP) in 1 min. under specific experimental condition. 


\section{Mycorrhizal colonization levels by vital and non- vital stains}

Mycorrhizal colonization levels expressed as frequency $(\mathrm{F} \%)$ and intensity $(\mathrm{M} \%)$ of mycorrhizal colonization. Meanwhile, percentage of arbuscular development (A \%) in root tissues of soybean plants detected either by tryban blue (TB, non-vital stain) or succinate dehydrogenase activity (SDH, vital stain) were significantly decreased by adding $\mathrm{P}$ to the soil table 4. TB fungal infection in the roots was much higher than SDH activity at all treatments of soybean plants. Among all mycorrhizal fungi used in this study, $G$. mosseae gave the highest levels of coloni-zation in soybean root tissues when grown in either amended or un-amended soil with phosphorus. No mycorrhizal colonization was observed in non-my-corrhizal plants.

Table (4): Effect of phosphate fertilization on the levels of mycorrhizal colonization [F, frequency of root colonization; M, Intensity of mycorrhizal colonization and A, arbuscular frequency] of soybean plants as indicated by vital and non-vital staining techniques.

\begin{tabular}{|c|c|c|c|c|c|c|c|}
\hline \multirow{2}{*}{\multicolumn{2}{|c|}{ Treatments }} & \multicolumn{6}{|c|}{ Frequency of mycorrhizae $(\%)^{*}$} \\
\hline & & \multicolumn{3}{|c|}{ Non vital stain (TB) } & \multicolumn{3}{|c|}{ Vital stain (SDH) } \\
\hline $\begin{array}{c}\mathrm{KH}_{2} \mathrm{PO}_{4} \text { dose } \\
(\text { g.kg-1 soil })\end{array}$ & AMF Inoculum & $\mathbf{F}$ & $\mathbf{M}$ & $\mathbf{A}$ & $\mathbf{F}$ & $\mathbf{M}$ & $\mathbf{A}$ \\
\hline \multirow{4}{*}{0.0} & Non-AMF & $0.0^{\mathrm{e}}$ & $0.0^{\mathrm{e}}$ & $0.0^{\mathrm{e}}$ & $0.0^{\mathrm{f}}$ & $0.0^{\mathrm{d}}$ & $0.0^{\mathrm{e}}$ \\
\hline & Glomus mosseae & $90.8^{\mathrm{a}}$ & $60.9^{\mathrm{a}}$ & $47.7^{\mathrm{a}}$ & $82.2^{\mathrm{a}}$ & $37.2^{\mathrm{a}}$ & $28.3^{\mathrm{a}}$ \\
\hline & Glomus monosporum & $80.1^{\mathrm{b}}$ & $52.5^{\mathrm{ab}}$ & $39.9^{\mathrm{b}}$ & $66.8^{\mathrm{b}}$ & $29.7^{\mathrm{ab}}$ & $22.1^{\mathrm{b}}$ \\
\hline & Gigaspora margarita & $60.9^{\mathrm{c}}$ & $45.3^{\mathrm{c}}$ & $29.8^{\mathrm{c}}$ & $45.3^{\mathrm{d}}$ & $22.8^{\mathrm{b}}$ & $15.7^{\mathrm{c}}$ \\
\hline \multirow{4}{*}{0.5} & Non-AMF & $0.0^{\mathrm{e}}$ & $0.0^{\mathrm{e}}$ & $0.0^{\mathrm{e}}$ & $0.0^{\mathrm{f}}$ & $0.0^{\mathrm{e}}$ & $0.0^{\mathrm{e}}$ \\
\hline & Glomus mosseae & $81.3^{\mathrm{b}}$ & $50.4^{\mathrm{b}}$ & $39.9^{\mathrm{b}}$ & $66.4^{\mathrm{b}}$ & $32.5^{\mathrm{ab}}$ & $23.6^{\mathrm{b}}$ \\
\hline & Glomus monosporum & $60.5^{\mathrm{c}}$ & $41.8^{\mathrm{c}}$ & $28.4^{\mathrm{c}}$ & $52.4^{\mathrm{c}}$ & $23.1^{\mathrm{b}}$ & $16.9^{\mathrm{c}}$ \\
\hline & Gigaspora margarita & $45.6^{\mathrm{d}}$ & $30.9^{\mathrm{d}}$ & $15.7^{\mathrm{d}}$ & $31.8^{\mathrm{e}}$ & $11.8^{\mathrm{c}}$ & $8.88^{\mathrm{d}}$ \\
\hline LSD (0.05) & & 9.9 & 8.77 & 5.42 & 12.5 & 6.67 & 3.99 \\
\hline
\end{tabular}

\section{Nutrient content}

Increasing phosphorus concentration in soil significantly increased nitrogen and phosphorus concentrations in the shoots and roots of mycorrhizal and non-mycorrhizal soybean plants table 5. Phosphorus and nitrogen contents in shoot and root tissues of the mycorrhizal plants were significantly higher than those in non-mycorrhizal soybean plants grown in P deficient soil. Such stimulations in nutr-ients content in response to the mycorrhizal effects were highly linked with the degree of each mycorr-hizal coloniz-ation in root tissues. Glomus mosseae inoculated plants exhibited the highest $\mathrm{P}$ and $\mathrm{N}$ cont-ents in shoot and root tissues compared to other mycorrhizal fungi in either soil amended with or without P table 5. On the other hand, no significant differences in $\mathrm{P}$ content in root tissues were observed between mycorrhizal and nonmycorrhizal soybean plants are grown in soil amended with soil phosphorus.

\section{Nodule formation}

Number and dry weight of root nodules were significantly increased both by increased soil phosphorus and mycorrhizal inoculation. At the same time, mycorrhizal fungi significantly increased the number and dry weights of nodules of soybean roots than equivalent non-mycorrhizal plants particularly at $\mathrm{P}$ deficient soil table 6.

The observed increase in nodule formation was highly linked to the rate of each mycorrhizal colonization. Glomus mosseae exhibited the highest number of the nodule in soybean roots when compared with other mycorrhizal fungi colonized soybean plants grown in soil with or without phosphorus fertili-zation. On the other hand, the increase of nodule formation resulting in mycorrhizal colonization de-creased as soluble phosphate fertilizer was added to the soil.

\section{DISCUSSION}

Phosphorus is an extremely important nutrient for plant growth and production of legumes and its deficiency can highly limit plant growth (Abdel-Fattah et al., 2014; Liu et al., 2015; Higo et al., 2018). At the same time, phosphorus is the most difficult nutrient for the plant to gain. In soil, phosphorus may be present in a moderately large amount, but much of it is poorly available to plants due to its low mobility in the soil (Wakelin et al., 2012). At the moment, uptake of the phosphate by root hairs leads to decreasing of phosphate concentration in the exhaustion zones (Rhizosphere) because replacement does not keep pace 
with uptake. Accordingly, the plant has evolved a range of approaches that increase the availability of phosphorus in the soil (Zhao et al., 2017; Wang et al., 2017). One of the most common strategies is arbuscular mycorrhizal (AM) symbiosis (Abdel-Fattah,
1997; Smith et al., 2011; Sheng et al., 2013; Gosling et al., 2016; Filho et al., 2017). In the present study, arbuscular mycorrhizal fungi significantly increased the shoot height, fresh and dry matters of shoots and roots of soybean plants grown in soil amended with or

Table (5): Phosphorus (P) and nitrogen (N) concentrations in shoots and roots of mycorrhizal and non-mycorrhizal soybean plants grown in a sterilized soil with or without addition of phosphorus fertilizers.

\begin{tabular}{|c|c|c|c|c|c|c|c|}
\hline \multirow{2}{*}{\multicolumn{2}{|c|}{ Treatments }} & \multicolumn{6}{|c|}{ Parameter measured } \\
\hline & & \multicolumn{3}{|c|}{$\mathbf{P}(\%)$} & \multicolumn{3}{|c|}{$\mathbf{N}(\%)$} \\
\hline $\begin{array}{c}\mathrm{KH}_{2} \mathrm{PO}_{4} \text { dose } \\
(\text { g.kg-1 soil) }\end{array}$ & AMF status & Shoot & Root & Total & Shoot & Root & Total \\
\hline \multirow{4}{*}{$\mathbf{0}$} & Non-AMF & $0.14^{\mathrm{e}}$ & $0.11^{\mathrm{c}}$ & $0.25^{\mathrm{e}}$ & $2.61^{\mathrm{d}}$ & $1.67^{\mathrm{f}}$ & $4.28^{\mathrm{f}}$ \\
\hline & Glomus mosseae & $0.35^{\mathrm{c}}$ & $0.31^{\mathrm{b}}$ & $0.66^{\mathrm{c}}$ & $3.40^{\mathrm{ab}}$ & $2.55^{\mathrm{b}}$ & $5.95^{\mathrm{b}}$ \\
\hline & Glomus monosporum & $0.28^{\mathrm{d}}$ & $0.20^{\mathrm{d}}$ & $0.48^{\mathrm{d}}$ & $2.75^{\mathrm{c}}$ & $2.45^{\mathrm{c}}$ & $5.20^{\mathrm{d}}$ \\
\hline & Gigaspora margarita & $0.13^{\mathrm{e}}$ & $0.14^{\mathrm{c}}$ & $0.27^{\mathrm{e}}$ & $2.65^{d}$ & $1.85^{\mathrm{d}}$ & $4.50^{\mathrm{e}}$ \\
\hline \multirow[t]{2}{*}{$\operatorname{Mean}($ MD* \%) } & & $80.9^{A}$ & $96.9^{A}$ & $88.0^{A}$ & $12.4^{\mathrm{A}}$ & $36.7^{\mathrm{A}}$ & $21.9^{A}$ \\
\hline & Non-AMF & $0.37^{\mathrm{b}}$ & $0.33^{\mathrm{b}}$ & $0.70^{\mathrm{b}}$ & $2.90^{\mathrm{c}}$ & $2.28^{\mathrm{e}}$ & $5.18^{d}$ \\
\hline \multirow{3}{*}{0.5} & Glomus mosseae & $0.41^{\mathrm{a}}$ & $0.37^{\mathrm{a}}$ & $0.78^{\mathrm{a}}$ & $3.46^{\mathrm{a}}$ & $2.77^{\mathrm{a}}$ & $6.23^{\mathrm{a}}$ \\
\hline & Glomus monosporum & $0.38^{\mathrm{b}}$ & $0.32^{\mathrm{b}}$ & $0.70^{\mathrm{b}}$ & $3.20^{\mathrm{b}}$ & $2.55^{\mathrm{b}}$ & $5.75^{\mathrm{b}}$ \\
\hline & Gigaspora margarita & $0.35^{\mathrm{c}}$ & $0.31^{\mathrm{b}}$ & $0.66 \mathrm{c}$ & $2.95^{\mathrm{c}}$ & $2.44^{\mathrm{c}}$ & $5.39^{\mathrm{c}}$ \\
\hline Mean (MD* \%) & & $2.70^{B}$ & $1.01^{B}$ & $1.91^{\mathrm{B}}$ & $7.14^{\mathrm{AB}}$ & $13.5^{\mathrm{B}}$ & $11.8^{\mathrm{B}}$ \\
\hline LSD (0.05) & & 0.15 & 0.09 & 0.11 & 0.44 & 0.24 & 0.99 \\
\hline
\end{tabular}

Mycorrhizal dependency $\left(\mathrm{MD}^{*}\right)=[(\mathrm{M}-\mathrm{NM}) / \mathrm{NM}] \times 100$, where $\mathrm{M}$ is the mean value of each parameter of three mycorrhizal treatments and NM is parameter value of non-mycorrhizal treatment. Values of mycorrhizal treatments or MD separately in each column either followed by the same letter(s) are not significantly different at $p \leq 0.05$ (Duncan's multiple range test). Each value represents the mean of 5 replicates and LSD represents the values between mycorrhizal treatments.

Table (6): Effect of phosphate fertilization and different species of mycorrhizal colonization on nodule formation of soybean plants grown in a sterilized soil.

\begin{tabular}{|c|c|c|c|}
\hline Treatments & & Nodule formation & \\
\hline $\begin{array}{l}\mathrm{KH}_{2} \mathrm{PO}_{4} \\
\text { dose } \\
\text { (g.kg } \\
\text { (-1 soil) }\end{array}$ & AMF status & $\begin{array}{c}\text { Number of } \\
\text { nodules plant }^{-1}\end{array}$ & $\begin{array}{l}\text { Nodule dry wt. } \\
\left(\text { g plant }^{-1}\right)\end{array}$ \\
\hline \multirow[t]{4}{*}{$\mathbf{0}$} & Non-AMF & $65^{\mathrm{d}}$ & $84.1^{\mathrm{d}}$ \\
\hline & Glomus mosseae & $153^{\mathrm{b}}$ & $147.5^{\mathrm{c}}$ \\
\hline & Glomus monosporum & $120^{\mathrm{c}}$ & $130.2^{\mathrm{c}}$ \\
\hline & Gigaspora margarita & $85^{\mathrm{d}}$ & $105.9^{\mathrm{d}}$ \\
\hline Mean (MD* \%) & & $73.3^{\mathrm{a}}$ & $52.1^{\mathrm{a}}$ \\
\hline \multirow[t]{4}{*}{0.5} & Non-AMF & $143^{\mathrm{b}}$ & $200.3^{b}$ \\
\hline & Glomus mosseae & $175^{\mathrm{a}}$ & $268.3^{\mathrm{a}}$ \\
\hline & Glomus monosporum & $163^{\mathrm{a}}$ & $230.8^{\mathrm{b}}$ \\
\hline & Gigaspora margarita & $149^{\mathrm{b}}$ & $215.2^{\mathrm{b}}$ \\
\hline Mean (MD* \%) & & $13.5^{\mathrm{b}}$ & $18.9^{b}$ \\
\hline LSD (0.05) & & 20.5 & 35.2 \\
\hline
\end{tabular}

Mycorrhizal dependency $(\mathrm{MD} *)=[(\mathrm{M}-\mathrm{NM}) / \mathrm{NM}] \times 100$, where $\mathrm{M}$ is the mean value of each parameter of three mycorrhizal treatments and NM is parameter value of non-mycorrhizal treatment. Values of mycorrhizal treatments or MD separately in each column either followed by the same letter(s) are not significantly different at $p \leq 0.05$ (Duncan's multiple range test). Each value represents the mean of 5 replicates and LSD represents the values between mycorrhizal treatments. 
without phosphorus fertilization when comparing to non-mycorrhizal plants. Such stimulations in some growth criteria of plants resulted from mycorrhizal colonization were highly directly proportional to the respective level of each mycorrhizal colonization. In addition, the rate of growth in response to the mycorrhizal inoculation was more pronounced in Pdeficient soil. Furthermore, the increase in plant growth of soybean plants in response to mycorrhizal colonization may be ascribed mainly to assisting the plant in its acquisition of phosphorus and other nutrients (Liu et al., 2003; Abdel-Fattah et al., 2014; Karasawa and Takahashi, 2015; Sarabia et al., 2017).

Fertilization with soluble phosphate to soil significantly reduced the levels of mycorrhizal colonization of all used fungi in soybean root tissues stained either by trypan blue (non-vital stain) or succinate dehydrogenase (vital stain) and consequently the mycorrhizal growth response in associated soybean plants as compared with non-fertilized soils. These results are in agreement with other findings (Abdel-Fattah and Asrar 2012; Hart and Forsythe, 2012; Sheng et al., 2013; Higo et al., 2018). In addition, it is evident from the present study that not all root infection was metabolically active and then the rate of plant growth of soybean plants in response to mycorrhizal inoculation was not directly related to the level of mycorrhizal infection stained by trypan blue. These results supported the previous conclusions that this parameter is not a good indicator of arbuscular mycorrhizal efficiency for plant growth and nutrient contents (Schubert and Hayman 1986; Vierheilig and Ocampo, 1989; Guillemin et al., 1995; Abdel-Fattah et al., 2014). The degree of mycorrhizal infection staining for SDH activity was less than that with trypan blue. A decline in the proportion of metabolically active arbuscular with mycorrhizal development in the present results supported the observation of Kough et al., (1987), Hamel et al., (1990), Smith et al., (1990) and Abdel-Fattah (1997).

Phosphorus and nitrogen concentrations in shoots and roots of the mycorrhizal and non-mycorrhizal soybean plants increased with the addition of phosphorus fertilizer to the soil. But, mycorrhizal plants had higher concentrations of $\mathrm{P}$ and $\mathrm{N}$ in both roots and shoots than those in the non-mycorrhizal plants, particularly at $\mathrm{P}$ deficient soil. Such stimulations in $\mathrm{P}$ and $\mathrm{N}$ contents in response to mycorrhizal effects were highly related to each mycorrhizal colonization used during this study. These results are in agreement with other authors (Beauregard et al., 2013; Liu et al., 2017; Sarabia et al., 2017).

The activity of acid and alkaline phosphatase was significantly greater in mycorrhizal than in nonmycorrhizal root extracts of the soybean plants grown either in soil with or without phosphorus. Such increases in these activities were more marked in root extracts of soybean plants grown in phosphorus-deficient soil. Increase in phosphatase activities and growth responses of the soybean plants to AMF symbiosis were directly proportional to the levels of the mycorrhizal colonization. Among all mycorrhizal fun-gi used in this study, Glomus mosseas was the most efficient fungus for increasing protein and phos-phatases in the root extracts of plants. These results were in harmony with the previous observations (Abdel-Fattah and El-Katony 1996; Ibrahim et al., 2011, Smith et al., 2011; Gosling et al., 2013; Liu et al., 2015) who stated that mycorrhiza-specific phos-phatase (MPSase) was detected only in the root extract colonized with mycorrhizal fungi as compared to nonmycorrhizal root extract. The close relationship between the mycorrhizal growth responses and the intensity of the mycorrhizal colonization support the theory that the phosphatase enzymes are some way involved in the adaptation of $\mathrm{P}$ by AMF (Gianinazzi et al., 1979; Abdel-Fattah et al., 2014). Addition of soluble phosphate to soil significantly decreased the levels of the mycorrhizal colonization in root tissues of the soybean plants and therefore reduced the activities of acid and alkaline phosphatase in the mycorrhizal root extracts of the plants. Previous results have been reported in soybean and other plant species (Krishna et al., 1983; Wang et al., 2017). Arbuscular mycorrhizal inoculated soybean plants had higher contents of protein in root extracts than non-mycorrhizal plants grown either in the presence or absence of phosphorus fertilizers. The observed increase in protein contents in response to mycorrhizal colonization was highly pronounced in phosphorus-deficient soil (Gosling et al., 2016).

\section{CONCLUSIONS}

Arbuscular mycorrhizal (AM) inoculation significantly stimulated the growth of soybean plants grown in sandy loam soil (P-deficient soil). Nodulation percentage, photosynthetic pigments and phosphorus, and nitrogen contents were increased in sequences. Phosphatase activities of the soybean plants, particularly in P-deficient soil, recoded signif-icanthigh values. But, these benefits in response to mycorrhizal inoculation were greatly decreased with increasing phosphorus concentration in soil, suggesting that phosphorus inhibits the development of AMF and its function. Consequently, plants are grown in soil non-amended with phosphorus were signifi-cantly dependent on mycorrhizal fungi for enhancing growth, photosynthetic pigments, and $\mathrm{P}$ and $\mathrm{N}$ contents than plants grown in soil amended with phosphorus fertilization soils. In addition, by using vital stain for estimation of SDH within symbiotic fungi could provide a more significant evaluation of the efficiency of the fungal symbiosis for plant growth and nutrition.

\section{Acknowledgement}

The author would like to thank the Deanship of Scientific Research, Shaqra University, Saudi Arabia for supporting this work.

\section{REFERENCES}

ABDEL-FATTAH, G.M., 1997, Functional activity of VA-mycorrhiza (Glomus mosseae) in the growth 
productivity of soybean plants grown in sterilized soil. Folia Micrbiol. 41: 495-502.

ABDEL-FATTAH, G.M. AND A.A. ASRAR. 2012. Arbuscular mycorrhizal fungal application to improve growth and tolerance of wheat (Triticum aestivum L.) plants grown in saline soil. Acta Physiol Plant. 34: 267-277.

ABDEL-FATTAH, G.M. AND T.M. EL-KATONY. 1996. Effects of lime, nitrogen fertilization and VA-mycorrhizal fungi on growth, metabolic active ities and nutrient content of soybean grown in sterilized soil. Egypt. J. Bot. 36: 17-36.

ABDEL-FATTAH, G.M. A.A. ASRAR, S.M. ALAMRI AND E.M. ABDEL-SALAM. 2014. Influence of arbuscular mycorrhiza and phos-phorus fertilization on the gas exchange, growth and phosphatase activity of soybean (Glycine max L.) plants. Photosynthetica 52: 581-588.

AL-AMRI, S.M., M.H. AL-WHAIBI, G.M. ABDELFATTAH. AND M.H.SIDDIQUI. 2013. Role of mycorrhizal fungi in tolerance of wheat genotypes to salt stress. African J. Microbiol. Res. 7: 12861295.

AL-KAHTANI, H.A., 1989. Quality of soybeans and their crude oils in Saudi Arabia. J. Am. Oil Chem. Soc. 66: 109-113.

BEDUREGARD, M.S., M.P. GAUTHIER, C. HAMEL, T. ZHANG, T. WELACKY, C.S. TAN, AND M. AMAUD. 2013. Various forms of organic and inorganic $\mathrm{P}$ fertilizers did not negatively affect soil and root inhabiting AM fungi in a maizesoybean rotation system. Mycorrhiza 23: 143-154.

DAEI, G., M.R. ARDEKANI, F. REJALI, S. TEIMURI, AND M. MIRANSARI. 2009. Alleviation of salinity stress on wheat yield, yield components and nutrient uptake using arbuscular mycorrhizal fungi under field conditions. J. Plant Physiol. 166: 617-625.

EZAWA, T., AND T. YOSHIDA. 1994. Characterization of phosphatase in marigold roots infected with vesicular-arbuscular mycorrhizal fungi. Soil Sci. Plant Nutr. 40: 255-264.

FILHO, J.A., M.S. FREITAS, M.A. MARTINS, P.C. SANTOS, AND A.J. CARVALHO. 2017. Arbuscular mycorrhizal fungi and phosphate fertilization on star fruit tree seedlings. Agrari-Revista Brasileira de Ciencias Agrarias, 12: 14-19.

GIANINAZZI-PEARSON, V., AND S. GIANINAZZI. 1976. Enzymatic studies on the metabolism of vesicular-arbuscular mycorrhiza. I. Effect of mycorrhiza formation and phosphorus nutrition on soluble phosphatase activities in onion roots. Physiol.Veg., 14: 833-841.

GOSLING, P., A. MEAD, AND M. PROCTOR. 2013. Contrasting arbuscular mycorrhizal comm-unities colonizing different host plants show a sim-ilar response to a soil phosphorus concentration gradient. New Phytol. 198: 546-556.

GOSLING, P., J. JONES, AND C.D. BENDING. 2016. Evidence for functional redundancy in arbuscular mycorrhizal fungi and implications for agroecosystem management. Mycorrhiza 26: 77-83.
GUILLEMIN, J.P., M.O. OROZCO, V. GINANIAZZI-PEARSON, AND S. GIANINAZZI. 1995. Influence of phosphate fertilization on fungal alkaline phosphatase and succinate dehy-drogenase activities in arbuscular mycorrhiza of soybean and pineapple. Agric. Ecosyst. Environ. 23: 63-69.

HAMEL, E., H. FELLIS, AND D.L. SMRM. 1990. Measurement of development of endomycorrhizal mycelium using three different stains. New Phytol. 155: $297-302$.

HART, M.M., AND J.A. FORSYTHE. 2012. Using arbuscular mycorrhizal fungi to improve the nutrient quality of crops; nutritional benefits in addition to phosphorus. Scientia Horticulturae 148: 206-214.

HE, X.H., C. CRITCHLEY, AND C. BLEDSOE. 2003. Nitrogen transfer within and between plants through common mycorrhizal networks (CMNs). Crit. Rev. Plant Sci. 22: 531-567.

HIGO, M., Y. TAKAHASHI, K. GUNJI, AND K. ISOBEL.2018. How are arbuscular mycorrhizal Associations related to maize growth performance during short-term cover crop rotation? Journal of the Science of Food and Agriculture 98: 1388-1396.

HISCOX, J.D., AND G.F. ISRAELSTAM. 1979. A method for the extraction of chlorophyll from leaf tissue without maceration. Can. J. Bot. 57: 13321234.

HODGE, A., C.D. CAMPBELL, AND A.H. FITTER, (2001). An arbuscular mycorrhizal fungus accelerates decomposition and acquires nitrogen directly from organic material. Nature 413: 297-299.

IBRAHIM, H.A., G.M. ABDEL-FATTAH, F.M. EMAN, M.H. EL_AZIZ, AND A.E. ABD-SHOHR. 2011. Arbuscular mycorrhizal fungi and spermine alleviate the adverse effects of salinity stress on electrolyte leakage and productivity of wheat plants. Phyton-Ann Rel Bot. 51: 261-276.

JACKSON, M.L., 1973. Soil chemical analysis. Printice Hall of India Ltd.New Delhi.

KARASAWA, T., AND S. TAKAHASHI. 2015. Introduction of various cover crop species to improve soil biological $\mathrm{P}$ parameters and $\mathrm{P}$ uptake of the following crops. Nutrient Cycling in Agroecosystem 103: 15-28.

KOUGH, H., V. GIANINAZZI-PEARSON, AND S. GIANINAZZI. 1987. Depressed metabolic activity of vesicular-arbuscular mycorrhizal fungi after fungicide applications. New Phytol. 106: 707-715.

KRISHNA, K.R., D.J. BAGYARAJ, AND K.G. PAPAVINAS. 1983. Acid and alkaline phosphatase activities in mycorrhizal and uninfected roots of Arachis hypogaea L. Ann. Bot. 51: 551553.

LEHMAN, M., AND W.TAHERI, 2017. Soil microorganisms can reduce $\mathrm{P}$ loss from cropping system. In: Sustainable Agriculture Reviews. Springer International Publishing, pp. 15-36.

LIU, J.Y., L.A. BLAYLOCK, AND G. ENDRE. 2003. Transcript profiling coupled with spatial expression analysis reveals genes involved 
indistinct developmental stages of an arbuscular mycorrhizal symbiosis. Plant Cell 15: 2106-2123.

LIU, Y., N.C. JOHNSON, L. MAO, G. SHI, S. JIANG, G. DU, L. AN, AND H. FENG, 2015. Phylogenetic structure of arbuscular mycorrhizal community shifts in response to increasing soil fertility. Soil Biology and Biochemistry, 89: 196-205.

LIU, C.F., S. LIU, G.H. RAVNSKOV, Z. SUN, AND M.N. ANDERSEN. 2017. Impact of wood Biochar and its interactions with mycorrhizal fungi, phosphorus fertilization and irrigation strategies on potato growth. Journal of Agronomy and Crop Science 203: 131-145.

MENGE, J. A., JOHNSON, E.L. AND R.G. PLATT. 1978. Mycorrhizal dependency of several citrus cultivars under three nutrient regimes. New Phytol. 81: 553-559.

NELSON, D.W., AND L.E. SOMMERS. 1973. Determination of total nitrogen in plant material. Agro. J. 65: 109-112.

PHILLIPS, J.M. AND D.S. HAYMAN. 1970. Improved procedures for clearing roots and staining parasitic and vesicular-arbuscular mycorrhizal fungi for rapid assessment of infection. Trans. Brit. Mycol. Soc. 55: 158-161.

SAWERS, R.J.H., S.F. SVANE, C. QUAN, M. GRONLUND, B. WOZNIAK, M.N. GEBRESELASSIE, R.A. GONZALEZ-MUNOZ, I. BAXTER, J. GOUDER, I. JAKOBSE, U. PAZKOWSKI. 2017. Phosphorus acquisition efficiency in arbuscular mycorrhizal maize in correlated with abundance of root-external hyphae and the accumulation of transcripts encoding PHTI phosphate transporters. New Phytol. 214: 632-643.

SARABIA, M., P. CORNEJO, R. AZCON, Y. CARREON-ABUD, AND J. LARSEN. .2017. Mineral phosphorus fertilization modulates interactions between maize, rhizosphere yeasts and arbuscular mycorrhizal fungi. Rhizosphere 4:89-93.

SCHUBER, A., AND D.S. HAYMAN. 1986. Plant growth responses to vesicular-arbuscular mycorrhiza. XVI. Effectiveness of different endophytes at different levels of soil phosphate. New Phytol. 193: 79-90.

SHENG, M., R. LALANDE, C. HAMEL, AND N. ZLADI. 2013. Effect of long-term tillage and mineral phosphorus fertilization on arbuscular mycorrhizal fungi in a humid continental zone of Eastern Canada. Plant Soil 369: 599-613.

SMITH, S.E., I. JAKOBSEN, M. GRONLUND, AND F.A. SMITH. 2011. Roles of arbuscular mycorrhizas in plant phosphorus nutrition;
Interactions between pathways of phosphorus uptake in arbuscular mycorrhizal roots have important implications for understanding and manipulating plant phosphorus acquisition. Plant Physiol. 156: 1050-1057.

SMITH, S.E., AND V. GIANINAZZI-PEARSON. 1988 Physiological interactions between symbionts in vesicular-arbuseular mycorrhizal plants. Ann.Rev.Plam Physiol fol.Biol. 39: 221-244.

SMITH, S.E., AND V. GIANINAZZI-PEARSON. 1990. Phosphate uptake and vesicular-arbuscular activity in mycorrhizal Allium cepa L.: Effect of photon irradiance and phosphate nutrition. Australian J. Plant Physiol. 17: 177-188.

TANG, M., H. CHEN, J.C. HUANG, AND Z.Q. TINA, 2009. AM fungi effects on the growth and physiology of Zea mays seedlings under diesel stress. Soil Biol. Biochem. 41: 936-940.

TISSERANT, B., V. GIANINAZZI-PEARSON, S. GIANINAZZI, A. GOLLOTE. 1993. In planta histochemical staining of fungal alkaline phosphatase activity for analysis of efficient arbuscular endomycorrhizal infections. Mycol. Res. 97: 245-250.

TROUVELOT, A., J. KOUGH, AND V. GIANINAZZI-PEARSON. 1986. Evaluation of VA infection levels in root systems. Research for estimation methods having a functional significance. In: V. Gianinazzi-Pearson and S. Gianinazzi (eds.). Physiological and Genetical Aspects of Mycorrhizae.INRA Press, Paris, France, pp 217-221.

VIERHEILIG, H., AND J.A.OCAMPO. 1989. Relationships between SDH activity and VA mycorrhizai infection. Agric.Ecosyst.Environ. 29: 439-442.

WAKELIN, S., C. MANDER, C. GERARD, E. JANSA, J. ERB, A. YOUNG, S. CONDRON, AND L.M. O'CALLAGHAN, 2012. Response of soil microbial communities to contrasted histories of phosphorus fertilization in pastures. Applied Soil Ecology 61: 40-48.

WANG, C., P.J. WHITE, AND C.J. LI. 2017. colonization and community structure of arbuscular mycorrhizal fungi in maize roots at different depth in the soil profile respond differently to phos-phorus inputs on a long-term experimental site. Mycorrhiza 27: 369-369.

ZHAO, H., X. LI, Z. ZHANG, Y. ZHAO, J. YANG. AND Y. ZHU. 2017. Species diversity anddrivers of arbuscular mycorrhizal fungal communities in a semiarid mountain in China. Peer J. 5, e4155. 


\title{
أستجابة نباتات فول الصويا النامية في اراضي مستصلحة حديثة لانواع مختلفة من فطريات الميكروهيزا الأداخلية واري ملتسميد الفوسفورى
}

\author{
سالم بن عحم بن سالم العمري
}

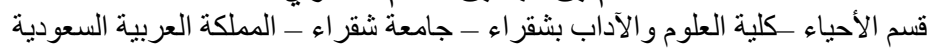

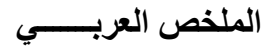

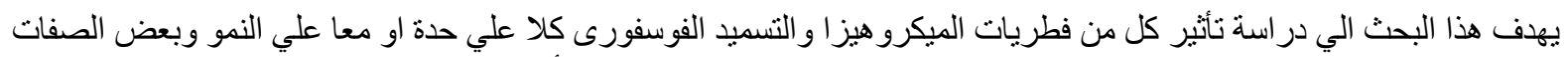

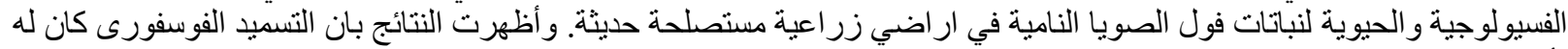

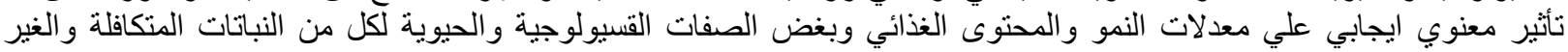

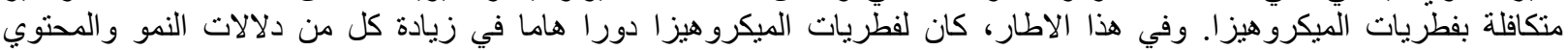

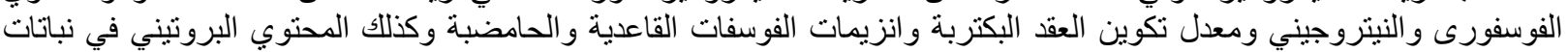

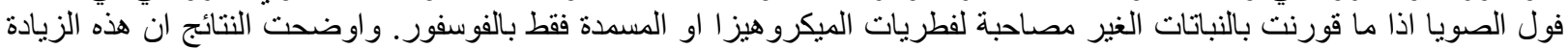

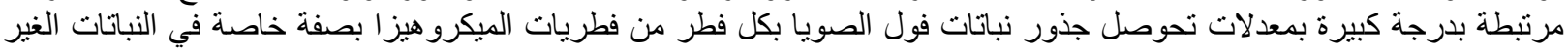

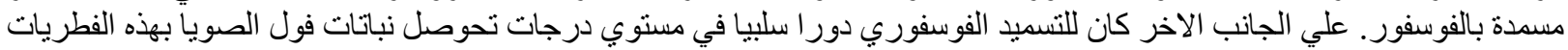

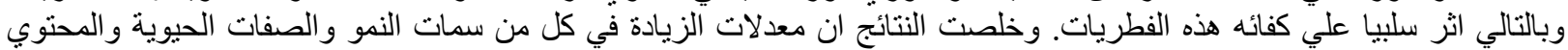

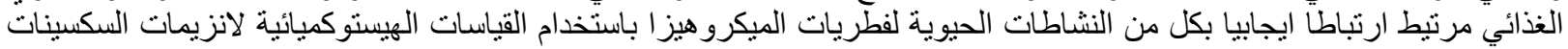

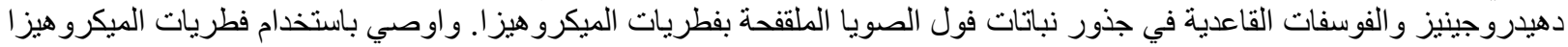

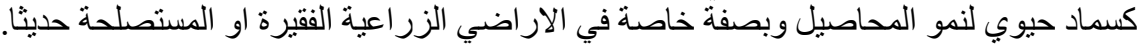

